\title{
Resource allocation in breeding seabirds: responses to fluctuations in their food supply
}

\author{
Alexander S. Kitaysky ${ }^{*}$, George L. Hunt Jr, Elizabeth N. Flint ${ }^{* *}$, \\ Margaret A. Rubega ${ }^{* * *}$, Mary Beth Decker****
}

Department of Ecology and Evolutionary Biology, University of California, Irvine, California 92697, USA

\begin{abstract}
In the vicinity of the Pribilof Islands in the Bering Sea, abundance of food available to surface-foraging seabirds was greater during the chick-rearing period in 1988 than in 1987, whereas abundance of food available to pursuit-diving seabirds was greater in 1987. Here we examine how breeding success and resource allocation of surface-foraging black-legged kittiwakes Rissa tridactyla (BLKI) and pursuit-diving thick-billed murres Uria lomvia (TBMU) varied with the fluctuations in their food supply. We also examine a difference in resource allocation among parents raising chicks at the large colony on St. George Island and those at the nearby small colony on St. Paul Island. We studied breeding success (BS), field metabolic rates (FMR, assessed by using doubly labeled water), foraging distribution, and nest attendance of parents and growth rate (GR) of chicks. The BS of BLKIs was lower in 1987 (a season of less abundant food for kittiwakes) than in 1988 (a season of more abundant food), and parents had higher FMRs in 1987 than in 1988. At-sea distributions and nest attendance suggested that in 1987 BLKIs foraged farther from the colonies, which could have resulted in the higher FMR of the parents. GR of BLKI chicks did not vary between 1987 and 1988. The BS of TBMUs was not significantly different between 1987 (a season of more abundant food for TBMUs) and 1988 (a season of less abundant food). Parent TBMUs had similar FMRs between the seasons. Densities of foraging TBMUs were higher within $20 \mathrm{~km}$ around colonies in 1987 than in 1988. Although the total time parent TBMUs spent foraging did not vary inter-seasonally, they performed more foraging trips of a shorter duration in 1987 than in 1988, and the GR of TBMU chicks was higher in 1987 than in 1988. Inter-colony comparisons do not suggest that parents reproducing at the large colony work harder to raise their young compared to parents breeding at the small colony. In 1987 parent BLKIs failed in raising young at the large colony, whereas one-third of BLKIs fledged their chicks at the small colony. In 1988, however, RS and FMRs of parent BLKIs were not significantly different between the colonies. Also, TBMUs at the large colony had higher BS than those at the small colony in both 1987 and 1988. Furthermore, in both years parent TBMUs feeding young at the small colony foraged farther from the colony and had significantly higher FMRs than at the large colony. These results suggest that fluctuations in food supply affect resource allocation in seabirds. However, a decrease in food abundance is likely to cause an increase in energy expenditures of parent BLKIs, whereas growth rates of their chicks are less affected. For the TBMUs, food shortages are likely to cause a decrease in growth of the chicks, but not an increase in energy expenditures of the parents.
\end{abstract}

KEY WORDS: Doubly labeled water $\cdot$ Field metabolic rates $\cdot$ Food abundance $\cdot$ Kittiwakes $\cdot$ Murres

Resale or republication not permitted without written consent of the publisher

Present addresses:

*Department of Zoology, University of Washington, Box 351800, Seattle Washington 98195, USA.

E-mail: kitaysky@u.washington.edu

** US Fish and Wildlife Service, PO Box 50176, Honolulu, Hawaii 96850, USA

*** Department of Ecology and Evolutionary Biology, University of Connecticut, 1266 Storrs Road, Storrs, Connecticut 06269, USA

${ }^{* * * *}$ Horn Point Laboratory, University of Maryland, Center for Environmental Sciences, Cambridge, Maryland 21613, USA

\section{INTRODUCTION}

Field observations imply the possibility of a speciesspecific response of parent seabirds to variation in food resources (sensu Obst et al. 1995). Species-specific differences probably reflect behavioral/phylogenetic and ecological characteristics of seabirds and their prey, as was suggested for planktivorous and piscivorous alcids, Alcidae (Kitaysky 1996, Kitaysky \& Golubova 
2000). Results of field studies have shown that in some species of pelagic seabirds parents were willing and/or able to compensate for variation in food availability through an increase in effort devoted to foraging for the young (Burger \& Piatt 1990, Mognahan et al. 1994, Uttley et al. 1994). In other species, parents maintained constant foraging effort despite high variation in food availability (e.g., Obst et al. 1995).

Variations in the availability of food can also influence the reproductive performance of birds in a density-dependent fashion (Ashmole 1963, Furness 1984, Arcese \& Smith 1988, Both 1998). Several studies have shown that seabirds in large colonies have reduced chick survival or growth rates compared to birds in smaller colonies, suggesting greater depletion of food resources around large colonies (Gaston \& Nettleship 1981, Furness \& Birkhead 1984, Hunt et al. 1986). Reduced reproductive performance could indicate that adults at large colonies were not able to compensate fully for a depletion of food through an increase in their foraging effort. The lower rates of chick growth or survival in larger colonies could also reflect an unwillingness of adults to compensate for food shortages by increasing their reproductive investment. Instead, these parents may conserve resources to apply to future reproductive effort (Stearns 1992). Although there is considerable data demonstrating changes in seabird reproductive output as a function of prey resources (e.g., Ainley \& Boekelheide 1990, Hunt et al. 1996, Greenstreet et al. 1999, Hunt \& Byrd 1999), the behavioral responses of parent seabirds to variation in food resources are not well understood (Furness \& Nettleship 1991, Montevecchi 1993). Theoretical considerations of parental effort in reproduction versus allocation of resources to maintenance suggest that even high environmental variability would not change optimal effort of long-lived parent seabirds in reproduction (e.g., Cooch \& Ricklefs 1994).

In this study we examined (1) whether parent seabirds adjust their reproductive effort to interannual variations in food resources, and (2) whether adult birds at a very large colony work harder to raise their chicks than parents at a smaller nearby colony.
Our goal was to determine the relationship among field metabolic rates, foraging and nest attendance behaviors of parents, and growth rates and survival (until fledging) of their chicks following a change in food abundance.

\section{MATERIAL AND METHODS}

Study system. We studied the breeding biology of black-legged kittiwakes Rissa tridactyla and thickbilled murres Uria lomvia on St. Paul and St. George Islands, Pribilof Islands, Bering Sea. These 2 colonies are $88 \mathrm{~km}$ apart and differ by an order of magnitude in the number of seabirds breeding on them (Table 1). Black-legged kittiwakes are surface-foraging birds that prey on pelagic fishes and invertebrates during chick-rearing, and provision their young by regurgitating stomach-loads of partially digested food (Decker et al. 1995). On the Pribilof Islands, kittiwakes lay 1 to 2 eggs but rarely raise 2 young (Braun \& Hunt 1983). Thick-billed murres are pursuit-divers, and at the Pribilof Islands they concentrate their foraging within 30 to $60 \mathrm{~km}$ of each island (Hunt et al. 1982, Schneider \& Hunt 1984). Murres raise a single chick per successful breeding bout. Parent murres typically provision their chick with a single prey item that they deliver to the breeding site in the bill (Gaston \& Jones 1998).

An interannual change in food distribution and abundance observed at the Pribilof Islands during 1987 and 1988 (Coyle \& Cooney 1993, G.L.H. et al. unpubl. data) allowed us to study a change in resource allocation of kittiwake and murre parents in response to this inter-annual fluctuation. Overall, there were no significant inter-annual changes in the diet composition of black-legged kittiwakes and thick-billed murres during 1987 and 1988 (Decker et al. 1995). However, food available to surface-foraging kittiwakes was more abundant in 1988 compared to 1987, whereas food available to pursuit-diving murres was more abundant in 1987 than in 1988 (Table 2).

Breeding success. To examine the contributions of the interannual change in food abundance on the

Table 1. Estimates of the numbers of seabirds breeding on the Pribilof Islands, Bering Sea

\begin{tabular}{|c|c|c|c|c|}
\hline & \multicolumn{2}{|c|}{ St. Paul Island } & \multicolumn{2}{|c|}{ St. George Island } \\
\hline & $1976^{\mathrm{a}}$ & $1980 \mathrm{~s}^{\mathrm{b}, \mathrm{c}}$ & 1976 & $1980 \mathrm{~s}$ \\
\hline All seabirds & 267200 & 229400 & 2460500 & 2446000 \\
\hline Black-legged kittiwake Rissa tridactyla & 42000 & $\sim 20 \%$ decline & 94000 & $\sim 20 \%$ decline \\
\hline Thick-billed murre Uria lomvia & 110000 & $\sim 51 \%$ decline & 1400000 & $\sim 21 \%$ decline \\
\hline
\end{tabular}


Table 2. Estimates of abundance of prey potentially available to surface-foraging seabirds (determined by neuston trawls) and pursuit-diving seabirds (acoustically determined) during chick-rearing in 1987 and 1988 at the Pribilof Islands. Sampling by both methods was simultaneously performed in the vicinity of the Pribilof Islands in July and August of each year; data for 43 neuston trawl (0 to $1 \mathrm{~m}$ layer of water was sampled) tows are presented as number of trawls in which a particular type of prey was present or absent (G.L.H. unpubl. data); acoustically determined data are from Coyle \& Cooney (1993) (collected by $38 \mathrm{kHz}$ echo integration system; probably reflect abundance of fish and euphausiids [Coyle \& Cooney 1993], which were the main prey of thick-billed murres nesting on the Pribilof Islands in 1987 and 1988 [Decker et al. 1995]. Measures of prey abundance that were significantly different between years are in bold $(\mathrm{p}<0.001$, chi-square tests for neuston trawls, G.L.H. unpubl. data, and Student's $t$-tests for acoustically determined biomass: Coyle \& Cooney 1993)

\begin{tabular}{|c|c|c|c|c|c|}
\hline \multirow{2}{*}{ Prey } & \multicolumn{2}{|c|}{ Neuston trawls (present/absent) } & \multicolumn{2}{|c|}{ Acoustically determined biomass $\left(\mathrm{g} \mathrm{m}^{-3}\right)$} & \multirow[b]{2}{*}{1988} \\
\hline & 1987 & 1988 & 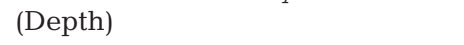 & 1987 & \\
\hline Fish & $3 / 40$ & $18 / 25$ & (5-30 m below surface) & 3.75 & 1.33 \\
\hline $\begin{array}{l}\text { Gelatinous } \\
\text { zooplankton }\end{array}$ & $5 / 38$ & $26 / 17$ & (Strata within $20 \mathrm{~m}$ above bottom) & 2.22 & 1.47 \\
\hline Crab larvae & $0 / 43$ & $33 / 10$ & & & \\
\hline
\end{tabular}

breeding performance of seabirds, we used available data on reproductive performance in 1987 and 1988 as summarized by Climo (1993) and Dragoo \& Dragoo (1994). For black-legged kittiwakes and thick-billed murres, breeding success was defined as the percentage of nests in which an egg was laid from which a chick fledged successfully. Consequently, to determine season and colony effects on bird breeding success, we used $\chi^{2}$-tests on relative frequences of nests where parents failed to fledge chicks or fledged chicks successfully.

Field metabolic rates. We determined field metabolic rates of parent kittiwakes and murres by using the doubly labeled water technique (Nagy 1983). We captured adults rearing young at their nests by net and/or noose pole. We then injected isotopically labeled water containing both ${ }^{3} \mathrm{H}$ and ${ }^{18} \mathrm{O}$ into the pectoralis major of the birds. The injection solution was suitably mixed to deliver $1 \mathrm{mCi}{ }^{3} \mathrm{H} \mathrm{kg}^{-1}$ bird (i.e., $0.4 \mathrm{mCi}$ kittiwake $^{-1}, 1.0 \mathrm{mCi}$ murre ${ }^{-1}$ ) and $3 \mathrm{ml}$ of 90 to 99 atom $\% \mathrm{H}_{2}{ }^{18} \mathrm{O} \mathrm{kg}^{-1}$ bird (i.e., $1.2 \mathrm{ml}$ kittiwake ${ }^{-1}, 3 \mathrm{ml}$ murre ${ }^{-1}$ ) in a single injection of $3.2 \mathrm{ml} \mathrm{kg}^{-1}$ per bird. Injections of this size are unlikely to disturb the birds' water balance, and are well below the accepted threshold for ${ }^{3} \mathrm{H}$ toxicity (Nagy \& Costa 1980). Injected individuals were held for $1 \mathrm{~h}$ (kittiwakes) or $1.5 \mathrm{~h}$ (murres) to allow the isotopes to equilibrate throughout the body-water space. During this period the individual was weighed, banded and marked with dye for later recognition. At the end of the equilibration period, an initial blood sample was collected from the brachial vein in a $70 \mu \mathrm{l}$ hematocrit tube and the tube was immediately flame sealed. The birds were then released back at their nests. After 1.5 to $4.5 \mathrm{~d}$ (kittiwakes) and 2 to $6 \mathrm{~d}$ (murres) following the injection, each bird was recaptured at its nest. A second blood sample was taken and sealed as before.
Blood samples were chilled $\left(2\right.$ to $4^{\circ} \mathrm{C}$ ) in the field and transported to the laboratory at University of California, Irvine. There, water was distilled from the blood samples according to the microdistillation technique described by Nagy (1983). Isotope analysis of the distilled water was performed in 2 steps at the laboratory of K. A. Nagy at University of California at Los Angeles. ${ }^{3} \mathrm{H}$ activity was determined via liquid scintillation spectrometry with samples counted to $1 \%$ errors. Levels of ${ }^{18} \mathrm{O}$ were measured via proton activation analysis (Wood et al. 1975, Nagy 1983).

To determine total body water, we used ${ }^{18} \mathrm{O}$ levels in initial blood samples via the isotope dilution-space method (Nagy 1983). $\mathrm{CO}_{2}$ production was calculated from initial and final isotope levels and total body water (Roby \& Ricklefs 1986). Field metabolic rates (FMRs) were calculated from $\mathrm{CO}_{2}$ production by using the energy equivalent of each species' diet composition at each colony during the 1987 and 1988 breeding seasons (Decker et al. 1995).

FMR samples at the 2 colonies/years were controlled for brood size and age of chicks. For statistical comparisons of adult FMRs between colonies and reproductive seasons, we used ANOVA on mass-independent FMRs, where year and colony were the factors. To calculate mass-independent FMRs, we followed the ANCOVA method described by Packard \& Boardman (1987a,b). Specifically, to eliminate the effects of body mass on field metabolic rates, we used the ANCOVA on $\log _{10}$ FMR with colony/year as factors and $\log _{10}$-transformed body mass as a covariate. Then, the mass-independent FMR was calculated by using the common slope as the basis for FMR adjustments for body mass.

Nest-attendance observations. In this study, we considered each individual nest as a sampling unit. We assumed that, when parents were not observed at the nest site, they were foraging. Therefore, for each nest 
Table 3. Rissa tridactyla and Uria lomvia. Dates (mo/d) and sample sizes (No. of nests) of nest watches in this study. Min/nest = observation time

\begin{tabular}{|c|c|c|c|c|c|c|}
\hline \multirow{2}{*}{ Year } & \multirow{2}{*}{\multicolumn{2}{|c|}{$\begin{array}{l}\text { St. Paul Island } \\
\text { No. of nests }\end{array}$}} & \multirow[b]{2}{*}{ Min/nest } & & \multirow{2}{*}{$\begin{array}{l}\text { St. George Island } \\
\text { No. of nests }\end{array}$} & \multirow[b]{2}{*}{ Min/nest } \\
\hline & & & & Date & & \\
\hline \multicolumn{7}{|c|}{ Black-legged kittiwake } \\
\hline 1987 & 8/9-8/11 & 5 & 2460 & & & \\
\hline \multirow[t]{2}{*}{1988} & $7 / 29-7 / 31$ & 7 & 2880 & $7 / 20-7 / 22$ & 5 & 2870 \\
\hline & $8 / 10-8 / 12$ & 4 & 3570 & & & \\
\hline \multicolumn{7}{|c|}{ Thick-billed murre } \\
\hline \multirow[t]{2}{*}{1987} & 8/4-8/5 & 3 & 1590 & $8 / 10-8 / 12$ & 4 & 3450 \\
\hline & $8 / 14-8 / 16$ & 4 & 2760 & $8 / 11-8 / 18$ & 4 & 3200 \\
\hline \multirow[t]{2}{*}{1988} & $8 / 6-8 / 7$ & 12 & 2045 & $8 / 4-8 / 6$ & 9 & 3540 \\
\hline & $8 / 13-8 / 14$ & 6 & 860 & $8 / 11-8 / 14$ & 7 & 3600 \\
\hline
\end{tabular}

we calculated: (1) mean number of trips per parent per day, (2) mean duration of foraging trip (time between consecutive departure and arrival of a parent), (3) time chicks spent alone (with no parents present at the nest site), and (4) parent loafing time (time both parents were simultaneously observed at the nest site). We conducted 9 direct watches (each of $48 \mathrm{~h}$ or longer duration) of 49 kittiwake and 21 murre nests (Table 3). No nests were observed twice during this study. At least 1 member of a pair was individually marked,

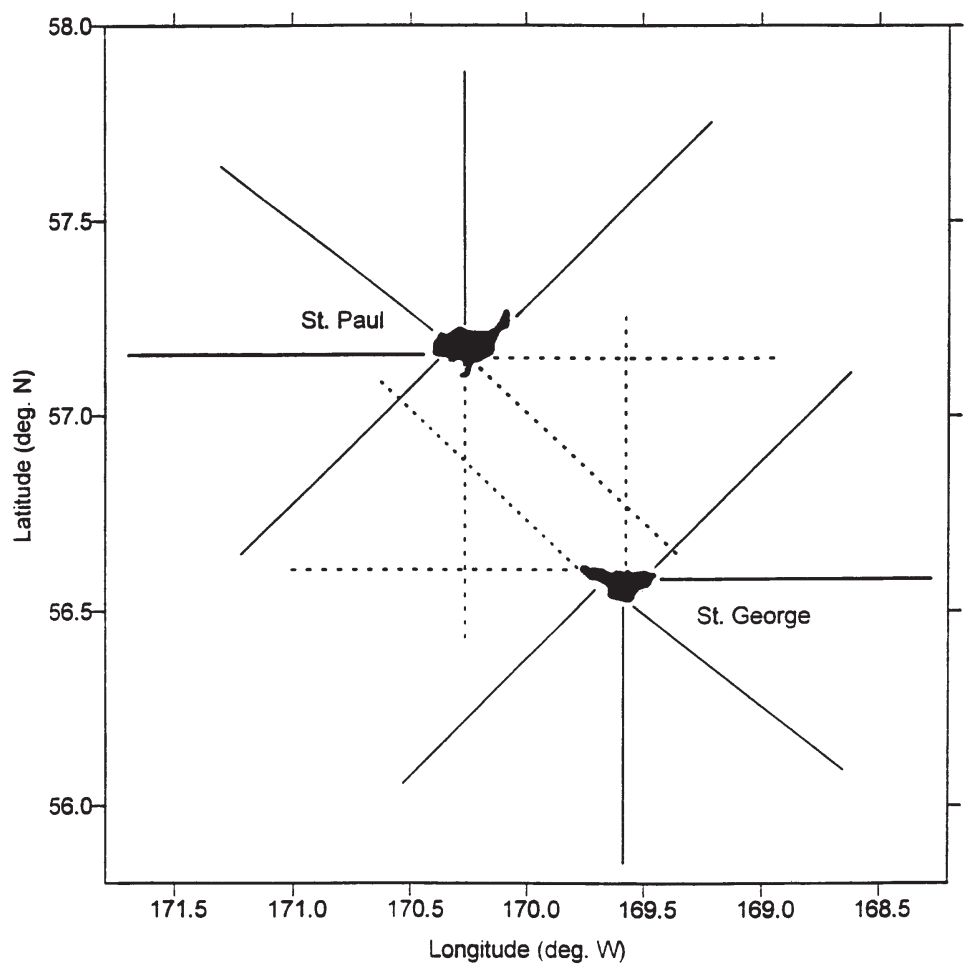

Fig. 1. Map of at-sea transects. Dotted lines = transects that overlap in relation to colony position and thus were excluded from statistical analyses which allowed us to determine arrival and departure time for each individual parent. Because on some occasions (see Table 3) nest watches were carried out twice (each time using different nests) during the chickrearing period, we tested for the effect of date on nest-attendance parameters. Date of observations did not affect the measured parameters significantly, so we combined the data for statistical purposes. Finally, we analyzed the data with Student's $t$-tests, where colony and year were used as factors.

At-sea observations. To determine the foraging distribution of adult birds at sea around the Pribilof Islands, we conducted surveys from 26 July to 17 August 1987 and from 28 July to 21 August 1988. At-sea observations were made twice during each year along $74.2 \mathrm{~km}$-long transects radiating out from each island (Fig. 1). Continuous counts were made from the bridge of the RV 'Alpha Helix' while underway at 14.8 to $18.5 \mathrm{~km} \mathrm{~h}^{-1}$. All birds within an arc from $300 \mathrm{~m}$ ahead of the ship to $90 \%$ off the side with the best visibility were counted, and data were entered into a hand-held computer. Birds were recorded as flying, on water, feeding, or shipfollowing; however, ship-following birds were excluded from the analyses presented here.

We calculated the densities of murres (common, thick-billed and unidentified) recorded on water and feeding, and blacklegged kittiwakes recorded as flying, on water and feeding in $9.3 \mathrm{~km}$ 'bins' along a given transect. At this spatial scale, bird densities in adjacent areas were not statistically autocorrelated and can be considered independent samples (Decker 1995). To compare bird distribution between the colonies and reproductive seasons, we carried out ANOVA, where year, colony, and distance from island were used as factors. 
Chick growth rates. Chick growth rates were measured at each colony by weighing chicks every 3 to $4 \mathrm{~d}$. For each chick, we estimated an increment in bodymass as a regression slope of mass on age during the linear phase of chick growth. The linear phase of bodymass increments occurs between 6 and $22 \mathrm{~d}$ post-hatch in the black-legged kittiwake (Barret \& Runde 1980), and between 0 and $14 \mathrm{~d}$ post-hatch in the thick-billed murre (Gaston \& Jones 1998). Accordingly, we restricted our analyses of chick growth to these periods. We restricted our analyses of chick growth to the nests that contained single-chick broods and considered each individual chick as a sample unit. In addition to examining variation in chick growth in 1987 and 1988, we also examined inter-annual and inter-colony variations in chick growth (data were collected as described above) for the time period 1976 to 1986. We analyzed these data as they help us to interpret the relationships between resource allocation and variation in chick growth that were observed in 1987 and 1988.

Statistical procedure. During the statistical analyses, data were tested for the assumptions required by a statistical test (according to Sokal \& Rohlf 1981). If data violated assumptions for parametric tests, then their non-parametric equivalents were used. For all computations, we used the SYSTAT statistical package (Wilkinson 1992). Statistical significance was assumed if $\mathrm{p}<0.05$.

\section{RESULTS}

\section{Breeding success}

In both colonies in 1987 (lower food abundance for surface-foraging seabirds), black-legged kittiwakes Rissa triclactyla had lower reproductive success than in 1988 (higher food abundance) (Table 4). In 1987, breeding success was higher at the small colony on St.
Paul Island than at the large colony on St. George Island. In 1988, breeding success was not significantly different between the colonies. Breeding success of thick-billed murres Uria lomvia did not vary interannually during 1987 and 1988, but in both years it was significantly higher among the birds nesting on St. George Island than for those on St. Paul Island (Table 4). Variation in breeding success was not related to predation. Nests at the sites studied were not vulnerable to arctic foxes Alopex lagopus and no avian predators were present in the study area in either year.

\section{Field metabolic rate}

During the 1987 breeding season when blacklegged kittiwakes had low breeding success at St. Paul Island and completely failed in their breeding attempt at St. George Island, parents at St. Paul Island showed higher FMRs than in $1988\left(F_{1,21}=14.431, \mathrm{p}=0.001\right.$, Fig. 2). FMRs were similar between the colonies in $1988\left(F_{1,23}=1.969, \mathrm{p}=0.174\right.$, Fig. 2$)$, when breeding success of these birds was high at both islands relative to historic values (Climo 1993, Dragoo \& Dragoo 1994).

For thick-billed murres, FMRs of parent birds were similar between the 1987 and 1988 breeding seasons (Fig. 3) (year effect: $F_{1,33}=1.60, \mathrm{p}=0.215$ ). However, FMRs of murres breeding at St. Paul Island were consistently higher than those of birds at St. George Island (Fig. 3) (colony effect: $F_{1,33}=1352.38, \mathrm{p}<0.001$; colony $\times$ year interaction term: $F_{1,33}=2.541, \mathrm{p}=0.120$ ).

\section{Nest attendance}

There were significant inter-seasonal differences in nest attendance of black-legged kittiwakes and thickbilled murres breeding on the Pribilof Islands in 1987 and 1988. For parent black-legged kittiwakes on St.

Table 4. Rissa tridactyla and Uria lomvia. Reproductive success (no. of nests where parents failed or fledged their young successfully) of black-legged kittiwakes and thick-billed murres nesting on the Pribilof Islands during 1987 and 1988 . Statistically significant effects are shown in bold

\begin{tabular}{|c|c|c|c|c|c|c|}
\hline \multirow[t]{2}{*}{ Area } & \multicolumn{2}{|c|}{1987} & \multicolumn{2}{|c|}{1988} & \multicolumn{2}{|c|}{ Inter-seasonal comparison } \\
\hline & Failed & Fledged & Failed & Fledged & $\chi^{2}$ & $\mathrm{p}$ \\
\hline \multicolumn{7}{|l|}{ Black-legged kittiwake } \\
\hline St. George Island & 24 & 0 & 29 & 34 & 21.26 & $<0.0001$ \\
\hline St. Paul Island & 254 & 120 & 60 & 108 & 49.32 & $<0.0001$ \\
\hline Inter-colony comparison & $\chi^{2}=11.02$ & $\mathrm{p}<0.001$ & $\chi^{2}=2.06$ & $\mathrm{p}=0.151$ & & \\
\hline \multicolumn{7}{|l|}{ Thick-billed murre } \\
\hline St. George Island & 125 & 252 & 69 & 126 & 0.28 & 0.594 \\
\hline St. Paul Island & 395 & 397 & 159 & 158 & 0.01 & 0.932 \\
\hline Inter-colony comparison & $\chi^{2}=28.90$ & $\mathrm{p}<0.0001$ & $\chi^{2}=10.67$ & $p=0.001$ & & \\
\hline
\end{tabular}




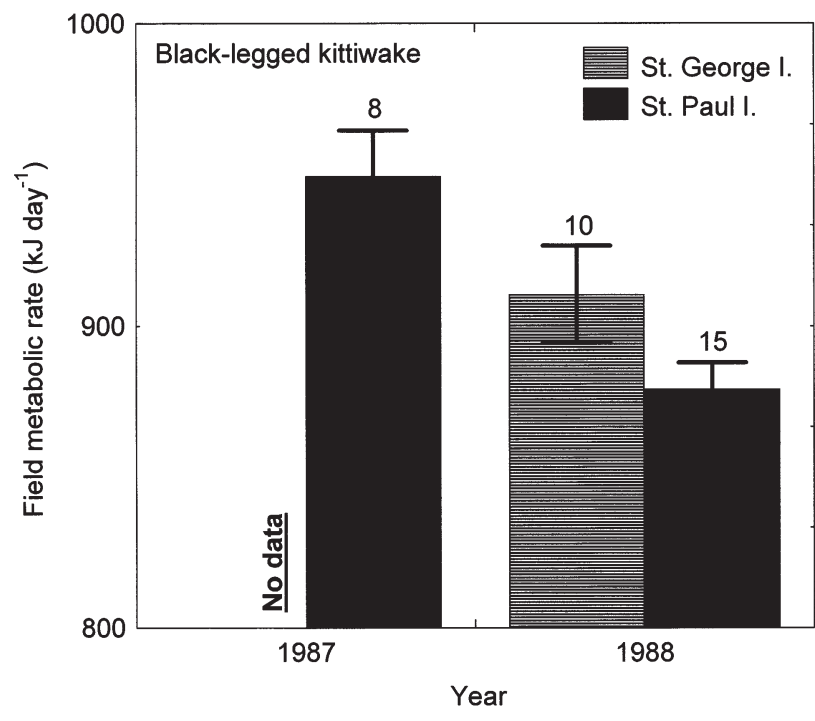

Fig. 2. Rissa tridactyla. Mass-independent field metabolic rates (means $\pm \mathrm{SE}$ ) of parent black-legged kittiwakes on the Pribilof Islands during 1987 (season of food shortages) and 1988 (season of abundant food for kittiwakes) reproductive seasons. Sample sizes shown above columns

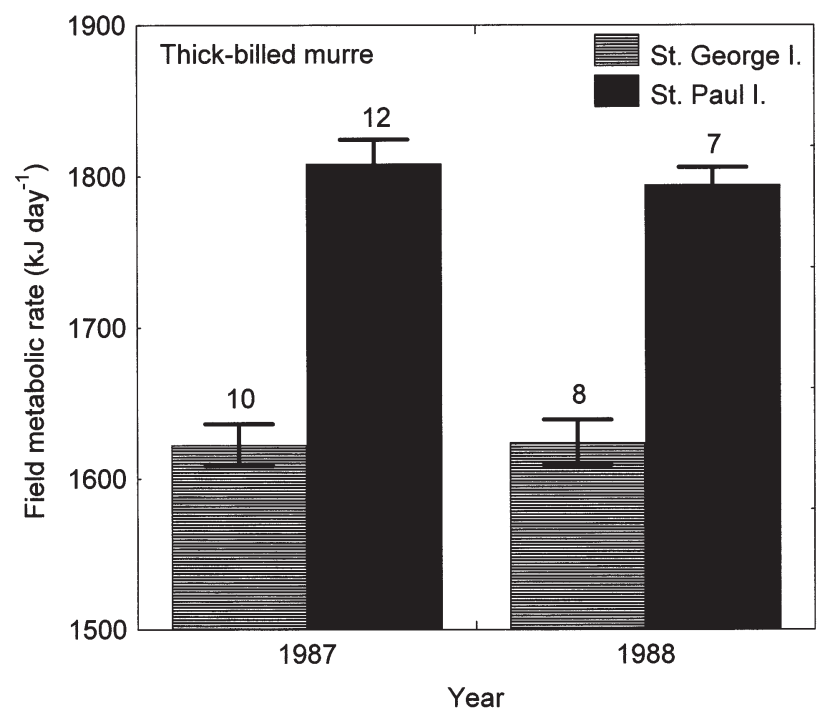

Fig. 3. Uria lomvia. Mass-independent field metabolic rates (means \pm SE) of parent thick-billed murres on the Pribilof Islands during 1987 (season of abundant food for murres) and 1988 (season of food shortages) reproductive seasons. Sample sizes shown above columns

Paul Island, foraging trips were longer in 1987 (lower food abundance) compared to 1988 (higher food abundance) (Table 5). This difference resulted in a significant increase of time spent by parents in foraging in 1987, even though the number of foraging trips per parent per day were similar in the 2 years (Table 5). Also, in 1987 kittiwakes on St. Paul Island left their chicks unattended for a greater proportion of time than in 1988 (Table 5). In 1988, the parameters of nest attendance by parent kittiwakes were similar on St. Paul and St. George Islands (Table 5). It was not possible to measure foraging trips at St. George Island in 1987 because black-legged kittiwakes completely failed to fledge young at the large colony (Table 4).

Thick-billed murres rearing chicks on St. George Island in 1987 performed more foraging trips per day compared to those on St. Paul Island in 1988 and 1987 and on St. George in 1988 (see colony effect in Table 6). The frequency of foraging trips did not change inter-seasonally on St. Paul Island, which resulted in a significant colony $\times$ year interaction term as shown in Table 6 . The duration of foraging trips was not significantly different between the 2 islands, and it was significantly shorter in 1987 than in 1988 (Table 6). Also, parent murres spent significantly less time loafing at the St. George colony during 1988 compared to 1987 and to the loafing time of murres on St. Paul Island in both years (colony effect in Table 6). In contrast to other parameters of nest attendance, the total time parent murres spent foraging was not significantly different between either colonies or years (Table 6).

\section{Foraging distribution of birds}

We found significant differences in the distribution of seabirds around the 2 islands. As expected, in 1988 black-legged kittiwakes were present in higher densities around St. George Island than St. Paul Island (colony effect as shown in Table 7 and Fig. 4). However, in 1987, kittiwake densities were similar around the 2 islands despite the higher number of birds breeding on St. George Island (a significant colony $\times$ year interaction term; Table 7, Fig. 4). Overall, more blacklegged kittiwakes were present around St. George Island in 1988 than in 1987 (year effect; Table 7, Fig. 4). Although there was no difference in overall kittiwake abundance around St. Paul Island in 1987 and 1988, more kittiwakes were found within the innermost survey interval ( 0 to $9.3 \mathrm{~km}$ ) of St. Paul Island in 1988 than in $1987(U=311.0, \mathrm{p}=0.010$ ) (Fig. 4). The distribution of black-legged kittiwakes with respect to distance from colony showed no significant differences between either the 2 islands or years (colony $\times$ distance, year $\times$ distance, colony $\times$ year $\times$ distance interaction terms; Table 7, Fig. 4).

Foraging murres were more abundant around the larger colony on St. George Island than they were around the smaller colony on St. Paul Island in both 1987 and 1988, as expected (colony effect; Table 8, Fig. 5). However, murres from St. Paul Island tended to 
Table 5. Rissa tridactyla. Nest attendance (means [SE]) patterns of parent black-legged kittiwakes on the Pribilof Islands $\mathrm{n}=$ number of nests. Statistically significant effects are shown in bold

\begin{tabular}{|c|c|c|c|c|c|}
\hline Colony & Year & $\begin{array}{l}\text { No. of foraging } \\
\text { trips }^{\mathrm{a}}\left(\text { trips d }^{-1}\right)\end{array}$ & $\begin{array}{l}\text { Foraging trip dur- } \\
\text { ation }^{\mathrm{a}}\left(\min \text { trip }^{-1}\right)\end{array}$ & $\begin{array}{c}\text { Time chicks spent } \\
\text { alone }^{\mathrm{b}}(\%)\end{array}$ & $\begin{array}{l}\text { Total foraging } \\
\text { time }^{\mathrm{a}}\left(\mathrm{min} \mathrm{d}^{-1}\right)\end{array}$ \\
\hline St. Paul Island $(\mathrm{n}=5)$ & 1987 & $1.8(0.35)$ & $673.1(131.59)$ & $39.5(5.10)$ & $1050.2(45.01)$ \\
\hline St. Paul Island $(\mathrm{n}=11)$ & 1988 & $2.7(0.30)$ & $289.7(23.42)$ & $0.1(0.08)$ & $728.1(7.89)$ \\
\hline St. George Island $(\mathrm{n}=5)$ & 1988 & $3.2(0.31)$ & $235.9(20.18)$ & 0 & $718.1(1.05)$ \\
\hline \multicolumn{6}{|l|}{ Statistical tables: } \\
\hline \multicolumn{2}{|l|}{ Factor } & $t \quad \mathrm{p}$ & & & \\
\hline \multicolumn{2}{|c|}{ Inter-seasonal (St. Paul Island) } & 1.830 .088 & $U=53.0 \quad \mathrm{p}=\mathbf{0 . 0 0 4}$ & $U=55.0 \mathrm{p}<0.001$ & $F=129.4 \mathrm{p}<0.001$ \\
\hline \multicolumn{2}{|c|}{ Inter-colony (for 1988) } & $0.82 \quad 0.428$ & $t=1.42 \mathrm{p}=0.176$ & $U=25.0 \mathrm{p}=0.500$ & $F=0.694 \mathrm{p}=0.41 \mathrm{C}$ \\
\hline
\end{tabular}

forage at a greater distance from the colony than did murres from St. George Island (colony $\times$ distance interaction term; Table 8, Fig. 5). Within the $74 \mathrm{~km}$ radius around each island, the densities of feeding murres were similar during 1987 and 1988 (year effect; Table 8, Fig. 5). However, more murres were foraging within $9.3 \mathrm{~km}$ of St. George Island in 1987 than in 1988 ( $U=$ 174.0, p= 0.033, Fig. 5) but not at St. Paul Island (Fig. 5), which was reflected in a significant interaction term among colony, year and distance from colony (Table 8).

\section{Chick growth rates during 1987 and 1988}

Growth rates of black-legged kittiwake chicks were not significantly different between 1987 and 1988 on St. Paul Island $\left(F_{1,25}=1.28, p=0.270\right.$, Fig. 6$)$, or between the islands in $1988\left(F_{1,19}=0.08, \mathrm{p}=0.783\right.$, Fig. 6). As with foraging trip duration in 1987, we could not measure the growth rate of black-legged kittiwake chicks on St. George Island because black-legged kittiwakes failed in raising chicks at this large colony.

Growth rates of thick-billed murre chicks were higher in 1987 compared to 1988 (year effect, $F_{1,48}=$ 41.28, p < 0.001, Fig. 7) at both colonies (year $\times$ colony interaction, $F_{1,48}=0.01, \mathrm{p}=0.932$, Fig. 7). There were no differences in chick growth rates between the small and the large colonies $\left(F_{1,48}=0.891, \mathrm{p}=0.349\right.$, Fig. 7 ).

\section{Inter-annual variation in chick growth during 1975 to 1988}

Growth rates of black-legged kittiwake chicks varied inter-annually (CV [coefficient of variation] = $10.0 \%, \mathrm{n}=10$ ) between $13.0 \pm 0.61(\mathrm{SE}) \mathrm{g} \mathrm{d}^{-1}$ (in 1978 on St. George Island) and $16.7 \pm 0.57(\mathrm{SE}) \mathrm{g} \mathrm{d}^{-1}$ in 1978 on St. Paul Island (Fig. 8).

Table 6. Uria lomvia. Nest attendance (means [SE]) patterns of parent thick-billed murres on the Pribilof Islands. $\mathrm{n}=$ number of nests. Statistically significant effects are shown in bold

\begin{tabular}{|c|c|c|c|c|c|c|c|c|c|}
\hline Colony & Year & \multicolumn{2}{|c|}{$\begin{array}{l}\text { No. of foraging trips } \\
\left(\text { trips d }^{-1}\right)\end{array}$} & \multicolumn{2}{|c|}{$\begin{array}{l}\text { Foraging trip duration }{ }^{a} \\
\qquad\left(\operatorname{min~}^{-1}\right)\end{array}$} & \multicolumn{2}{|c|}{$\begin{array}{l}\text { Loafing time }^{\mathrm{b}} \\
\qquad(\%)\end{array}$} & \multicolumn{2}{|c|}{$\begin{array}{l}\text { Total foraging time } \\
\qquad\left(\operatorname{min~d~}^{-1}\right)\end{array}$} \\
\hline St. Paul Island $(\mathrm{n}=7)$ & 1987 & \multicolumn{2}{|c|}{$2.5(0.62)$} & \multicolumn{2}{|c|}{$272.9(63.35)$} & \multicolumn{2}{|c|}{$6.6(3.27)$} & \multicolumn{2}{|c|}{$503.6(68.17)$} \\
\hline St. Paul Island $(\mathrm{n}=8)$ & 1988 & \multicolumn{2}{|c|}{$2.9(0.46)$} & \multicolumn{2}{|c|}{$261.1(40.07)$} & \multicolumn{2}{|c|}{$5.3(1.34)$} & \multicolumn{2}{|c|}{654.7 (51.19) } \\
\hline St. George Island $(\mathrm{n}=18$ ) & 1987 & \multicolumn{2}{|c|}{$5.9(0.75)$} & \multicolumn{2}{|c|}{$162.0(23.53)$} & \multicolumn{2}{|c|}{$7.8(1.97)$} & \multicolumn{2}{|c|}{$766.1(81.65)$} \\
\hline St. George Island $(\mathrm{n}=16)$ & 1988 & \multicolumn{2}{|c|}{$2.9(0.43)$} & \multicolumn{2}{|c|}{$325.6(66.18)$} & \multicolumn{2}{|c|}{$2.6(0.62)$} & \multicolumn{2}{|c|}{$641.9(38.20)$} \\
\hline \multicolumn{10}{|l|}{ ANOVA tables: } \\
\hline Factor & $\mathrm{df}$ & $F$ & $\mathrm{p}$ & $F$ & $\mathrm{p}$ & $F$ & $\mathrm{p}$ & $F$ & $\mathrm{p}$ \\
\hline Colony & 1,45 & 5.38 & 0.025 & 1.57 & 0.216 & 5.22 & 0.027 & 2.19 & 0.146 \\
\hline Year & 1,45 & 3.20 & 0.080 & 5.42 & 0.024 & 0.21 & 0.646 & 0.02 & 0.896 \\
\hline Colony $\times$ Year & 1,45 & 5.62 & 0.022 & 2.51 & 0.120 & 2.47 & 0.123 & 2.48 & 0.123 \\
\hline
\end{tabular}


Table 7. Rissa tridactyla. Densities of black-legged kittiwakes around the Pribilof Islands, based on surveys conducted along transects in Fig. 1. $\mathrm{n}=$ number of $9.3 \mathrm{~km}$ adjacent bins along all transects (see 'Material and methods'). Statistically significant effects are shown in bold

\begin{tabular}{|c|c|c|c|c|c|c|c|}
\hline \multirow{3}{*}{ Year } & \multirow{2}{*}{\multicolumn{3}{|c|}{ St. George Island }} & \multirow{2}{*}{\multicolumn{4}{|c|}{ Bird density (birds $\mathrm{km}^{-2}$ ) }} \\
\hline & & & & & & Paul Is & \\
\hline & Mean & SE & $\mathrm{n}$ & & Mean & SE & $\mathrm{n}$ \\
\hline 1987 & 3.7 & $(0.45)$ & 37 & & 3.4 & $(0.38)$ & 38 \\
\hline 1988 & 8.2 & $(0.91)$ & 40 & & 3.5 & $(0.40)$ & 40 \\
\hline \multicolumn{8}{|l|}{ Statistical tables: } \\
\hline Factor & & $F$ & & $\mathrm{p}$ & & df & \\
\hline Colony & & 18.9 & & $<0.001$ & & 1,123 & \\
\hline Year & & 17.9 & & $<0.001$ & & 1,123 & \\
\hline Distance & & 3.0 & & 0.006 & & 7,123 & \\
\hline Colony $\times$ Year & & 14.2 & & $<0.001$ & & 1,123 & \\
\hline Colony $\times$ Distance & & 0.7 & & 0.704 & & 7,123 & \\
\hline Year $\times$ Distance & & 1.4 & & 0.209 & & 7,123 & \\
\hline Colony $\times$ Year $\times$ Distance & & 0.8 & & 0.597 & & 7,123 & \\
\hline
\end{tabular}

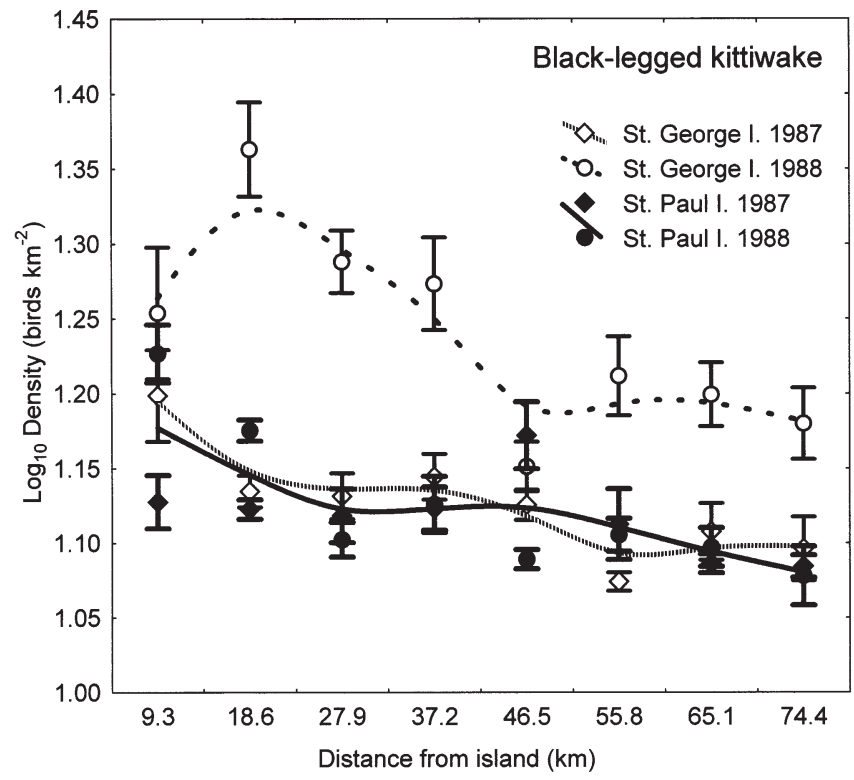

Fig. 4. Rissa tridactyla. Foraging distributions (means $\pm \mathrm{SE}$ ) in the vicinity of St. Paul and St. George Islands during 1987 and 1988. Each distance category is $9.3 \mathrm{~km}$ interval from each island (e.g. 9.3 on the graph $=$ distance interval of 0 to $9.3 \mathrm{~km}$ from the island). Lines $=$ linear regression slopes

Growth rates of thick-billed murre chicks varied inter-annually ( $\mathrm{CV}=25.4 \%, \mathrm{n}=12)$ between $6.1 \pm 0.37$ (SE) $\mathrm{g} \mathrm{d}^{-1}$ (in 1977 on St. George Island) and $13.1 \pm 0.73$ (SE) $\mathrm{g} \mathrm{d}^{-1}$ in 1978 on St. Paul Island (Fig. 9).

\section{DISCUSSION}

The goal of this study was to determine how a change in food abundance influences the allocation of resources by parent seabirds. We used an integrative approach relating the reproductive, behavioral and physiological responses of ecologically distinct species of seabirds to variation in food abundance and colony size. We found that resource allocation of parent seabirds reflected changes in food resources in a species-specific fashion.

At the Pribilof Islands, parents of black-legged kittiwakes Rissa tridactyla and thick-billed murres Uria lomvia feed their young with similar types of food (Decker et al. 1995). However, food available to surface-foraging kittiwakes was more abundant in 1988 than in 1987, whereas food available to pursuit-diving murres was more abundant in 1987 than in 1988 (Coyle \& Cooney 1993, G.L.H. unpubl. data summarized in Table 2). The results of our study of the reproductive biology and foraging distributions of kittiwakes and murres at the Pribilof Islands also suggest that food abundance and/or its availability varied in opposite ways for black-legged kittiwakes and thickbilled murres during 1987 and 1988.

\section{Resource allocation of black-legged kittiwakes}

Food resources available to foraging kittiwakes were more abundant in the vicinity of St. Paul Island in 1988 compared to 1987 (G.L.H. et al. unpubl. data, see Table 2). The results of this study suggest that during the year of less abundant food supply, parent blacklegged kittiwakes expanded their foraging range around the large colony at St. George Island. We found that black-legged kittiwake densities in 1988 were greater around St. George Island than St. Paul Island. The breeding colony on St. George Island is an order of magnitude larger than that at St. Paul Island. Thus, the 
Table 8. Uria lomvia. Densities of thick-billed murres around the Pribilof Islands, based on surveys conducted along transects in Fig. 1. $\mathrm{n}=$ number of $9.3 \mathrm{~km}$ adjacent bins along all transects (see 'Material and methods'). Statistically significant effects are shown in bold

\begin{tabular}{|c|c|c|c|c|c|c|c|}
\hline \multirow[t]{3}{*}{ Year } & \multirow{2}{*}{\multicolumn{3}{|c|}{ St. George Island }} & \multicolumn{2}{|c|}{ Bird density (birds $\mathrm{km}^{-2}$ ) } & & \\
\hline & & & & & \multicolumn{3}{|c|}{ St. Paul Island } \\
\hline & Mean & SE & $\mathrm{n}$ & & Mean & SE & $\mathrm{n}$ \\
\hline 1987 & 46.1 & $(23.3)$ & 37 & & 3.5 & $(0.63)$ & 38 \\
\hline 1988 & 19.2 & $(4.51)$ & 40 & & 6.5 & $(1.59)$ & 40 \\
\hline \multicolumn{8}{|l|}{ Statistical tables: } \\
\hline Factor & & $F$ & & $\mathrm{p}$ & & $\mathrm{df}$ & \\
\hline Colony & & 49.1 & & $<0.001$ & & 1,123 & \\
\hline Year & & 0.7 & & 0.414 & & 1,123 & \\
\hline Distance & & 19.9 & & $<0.001$ & & 7,123 & \\
\hline Colony $\times$ Year & & 1.3 & & 0.253 & & 1,123 & \\
\hline Colony $\times$ Distance & & 7.9 & & $<0.001$ & & 7,123 & \\
\hline Year $\times$ Distance & & 0.8 & & 0.618 & & 7,123 & \\
\hline Colony $\times$ Year $\times$ Distance & & 2.5 & & 0.022 & & 7,123 & \\
\hline
\end{tabular}

at-sea distribution of birds around the islands reflected the abundance of birds breeding at the colonies. However, there was no difference in black-legged kittiwake densities around the islands in 1987. We also found that around St. Paul Island there was no overall difference in black-legged kittiwake densities between years. These results suggest that during the year of less abundant food supply, kittiwakes breeding on

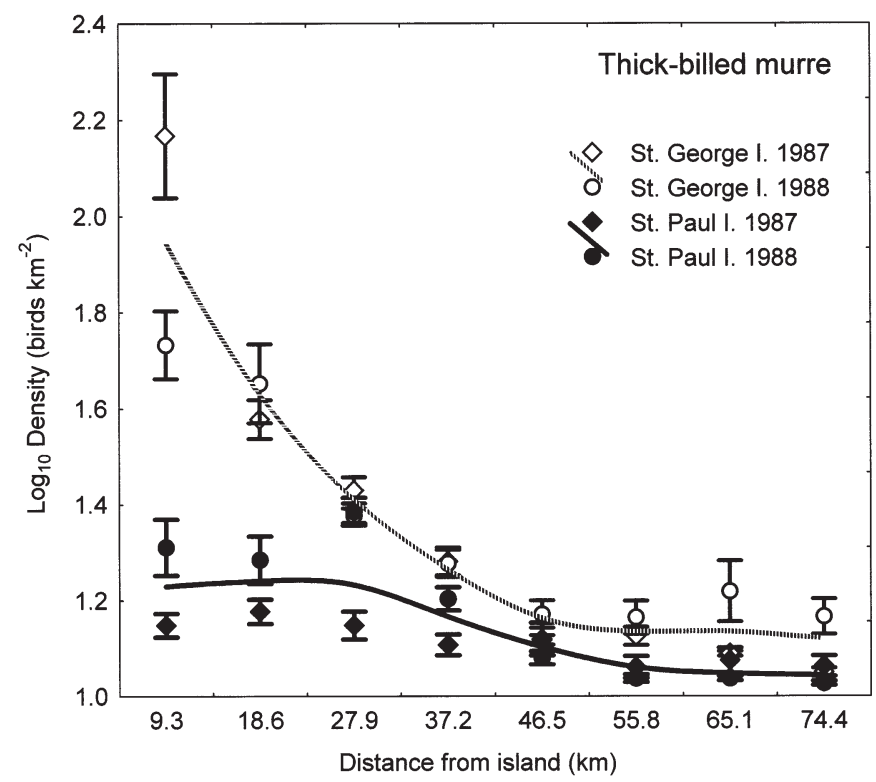

Fig. 5. Uria lomvia. Foraging distributions (means $\pm \mathrm{SE}$ ) around St. Paul and St. George Islands in 1987 and 1988. Thick-billed murres consitute approx. $90 \%$ of the murres breeding on these islands. Each distance category is $9.3 \mathrm{~km}$ interval from each island (e.g. 9.3 on the graph = distance interval of 0 to $9.3 \mathrm{~km}$ from the island). Lines = linear regression slopes the large colony may have foraged at greater distances from the colony than during the year with good foraging conditions.

Earlier reported measurements of FMRs in freeliving black-legged kittiwakes that were obtained with the double-labelled water technique (Gabrielsen et al. 1987) are similar to those measured in our study. In particular, Gabrielsen et al. reported daily energy expenditures of black-legged kittiwakes feeding chicks of between $596 \mathrm{~kJ} \mathrm{~d}^{-1}$ (for non-foraging birds) and $992 \mathrm{~kJ} \mathrm{~d}^{-1}$ (for foraging birds). The FMRs observed in our study are in the same range, from $831 \mathrm{~kJ} \mathrm{~d}^{-1}$ (for kittiwakes on St. Paul Island in 1988) to $903 \mathrm{~kJ} \mathrm{~d}^{-1}$ (for

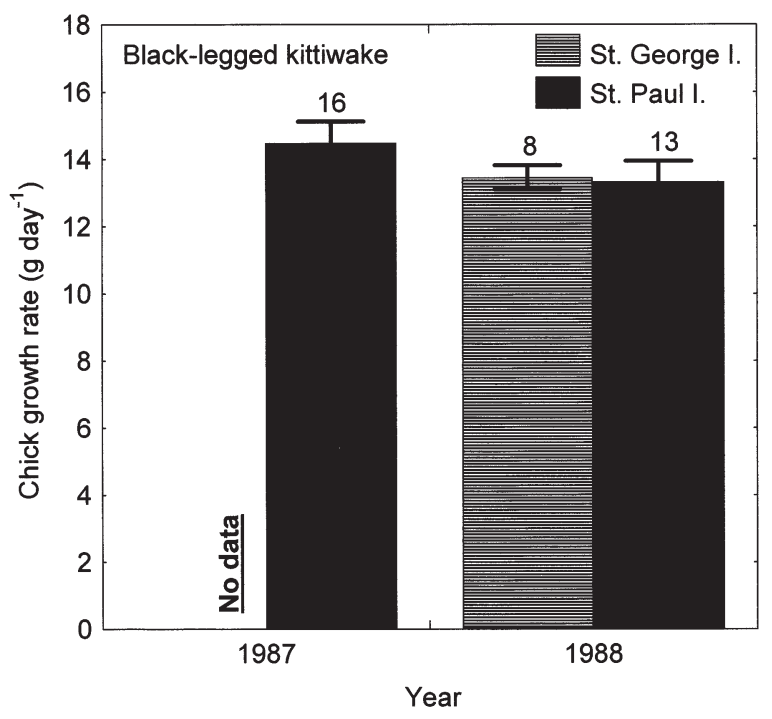

Fig. 6. Rissa tridactyla. Daily increments (means $\pm \mathrm{SE}$ ) of body mass of chicks on the Pribilof Islands during 1987 and 1988. Sample sizes shown above columns 


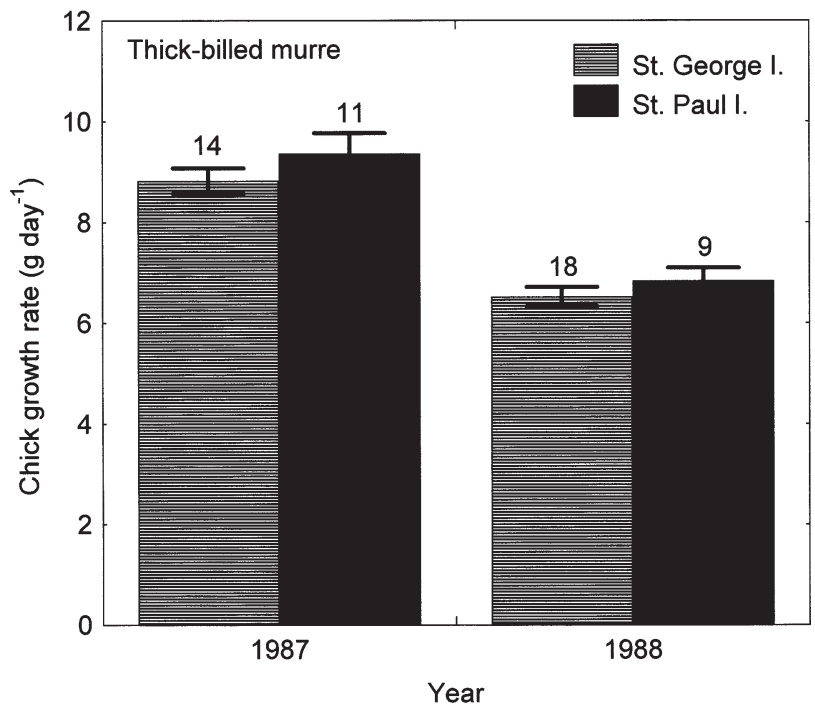

Fig. 7. Uria lomvia. Daily increments (means \pm SE) of body mass of chicks on the Pribilof Islands during 1987 and 1988. Sample sizes shown above columns

kittiwakes on St. Paul Island in 1987). Therefore, we have confidence that our measurements were within a reasonable range for this species. We found a significant change in the FMRs of parent black-legged kittiwakes between the 1987 and 1988 reproductive seasons. Changes in FMRs and nest attendance of parent kittiwakes observed in this study were in parallel with the change in food availability. Furthermore, our analysis did not indicate a significant difference in kittiwake chick growth rates between the 1987 and 1988

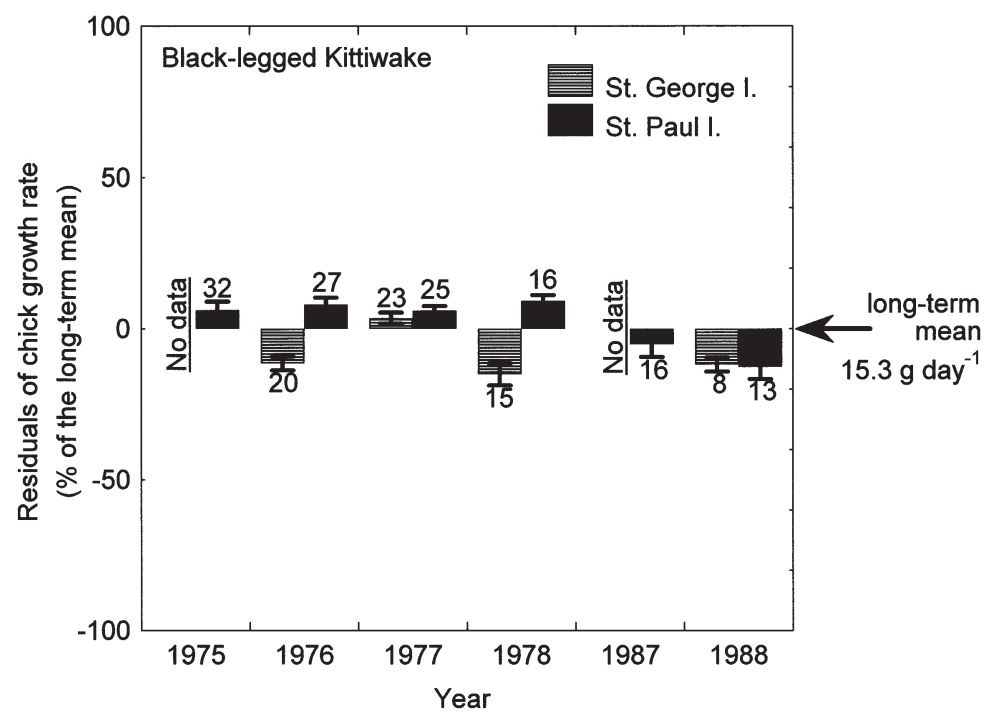

Fig. 8. Rissa tridactyla. Long-term variations in daily increments of chick body mass on the Pribilof Islands. 1987 and 1988 were 'poor' years for black-legged kittiwakes, especially on St. Paul Island breeding seasons on St. Paul Island. These findings imply that parent kittiwakes were able to compensate for food shortages in 1987 by allocating about 10\% more energy to foraging per day.

In contrast to a significant inter-seasonal variation in FMRs of parent kittiwakes on St. Paul Island, we did not find a difference in the FMRs and nest attendance of black-legged kittiwakes breeding on St. Paul and St. George Islands in 1988. We suggest that, when food was abundant, kittiwakes from the small and large colonies allocated similar amounts of available resources to reproduction and achieved similar results, as reflected in the similarity of overall breeding success between the colonies in 1988. However, during food shortages in 1987, black-legged kittiwakes breeding in the large colony failed, whereas kittiwakes breeding in the small colony were able to raise their chicks successfully, suggesting that colony size (Hunt et al. 1986) and/or intrinsic differences in distribution of food resources around the colonies (Schneider \& Hunt 1984) might have an important influence on the reproductive performance of these birds.

In black-legged kittiwakes, all parameters measured in this study point to a similar conclusion - when food is short, parents work harder, spend less time attending/guarding their chicks, and expand their foraging range in search for food. Similar changes in food availability might affect birds that breed in large colonies more strongly than those in small colonies. However, in this study we were able to compare only data from 2 colonies in 2 years. We could not and have not controlled for all factors affecting reproductive performance of black-legged kittiwakes. Thus, the importance of density-dependent factors for reproductive performance of kittiwakes remains to be shown.

\section{Resource allocation of thick-billed murres}

In contrast to black-legged kittiwakes, food resources available to pursuit-diving murres were more abundant during 1987 compared to 1988 (Coyle \& Cooney 1993, see Table 2). At-sea distributions indicate that murres foraged closer to St. George Island in 1987 than in 1988. We also recorded a longer duration of loafing time, more foraging trips per day, and shorter durations of foraging trips performed by parent thick-billed murres on St. George Island in 1987 than in 1988. This result also indicates that murres were foraging closer to the colony in 1987 than in 1988. Zador \& 


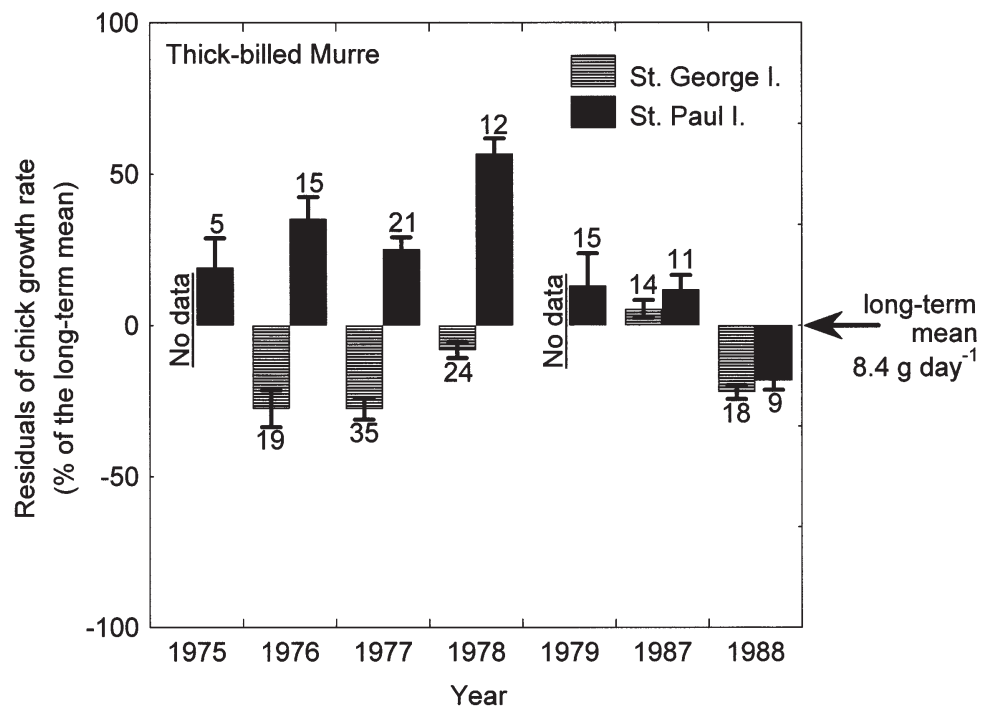

Fig. 9. Uria lomvia. Long-term variations in daily increments of chick body mass on the Pribilof Islands. 1988 was a 'poor' year for birds, especially on St. Paul Island, compared to the 1970s. Conversely, 1987 was an exceptionally 'good' year for birds on St. George Island

Piatt (1999) reported a similar result for the relationship between colony attendance and variation in food abundance in parent common murres Uria aalge. Thickbilled murres foraging closer to St. George Island in 1987 may explain why growth rates of chicks were higher in this year. One would expect growth rates of chicks to be higher if adults foraged closer to shore and were able to increase the delivery rates of food to the chicks. Comparisons of the amount of time parent thick-billed murres allocated to foraging showed no inter-annual and no inter-colony differences, suggesting that the growth rates of thick-billed murre chicks was determined mostly by variations in parental food provisioning rates.

The inter-seasonal change in food abundance did not affect the FMRs of parent thick-billed murres, suggesting that the reproductive effort of parent thick-billed murres was independent of inter-seasonal variation in foraging conditions. On the other hand, thick-billed murres breeding on St. Paul Island had higher daily energy expenditures than on St. George Island. Using a simple and robust model, Gaston (1985) predicted field metabolic rates of thick-billed murres breeding on Prince Leopold Island in relation to different estimates of foraging range and energy expenditure while foraging. Furthermore, predictions of this model were verified by direct measurments of FMRs of murres with doubly labelled water (A. Gaston unpubl. data, cited in Gaston 1985). Values predicted by this model are very similar to the measures of FMRs and foraging distributions of thick-billed murres observed in our study. According to the Gas- ton model (for birds spending $125 \mathrm{~kJ} \mathrm{~h}^{-1}$ while feeding), thick-billed murres with an FMR of $1623.4 \mathrm{~kJ} \mathrm{~d}^{-1}$ (as measured for birds nesting at St. George Island) could forage at a distance of about $4 \mathrm{~km}$ from nesting colonies. Thick-billed murres with an FMR of $1801.7 \mathrm{~kJ} \mathrm{~d}^{-1}$ as measured for birds at St. Paul Island) could forage at a distance of about $43 \mathrm{~km}$ from nesting colonies. These expected foraging distances generally match the observed foraging distribution of murres in our study. In particular, major densities of foraging murres were observed within a $10 \mathrm{~km}$ distance around St. George Island, and foraging murres were most abundant within $40 \mathrm{~km}$ distance around St. Paul Island (Fig. 5). These comparisons give us confidence in our FMR data, which suggest that thickbilled murres breeding on St. Paul Island invested approximately $12 \%$ more energy in reproduction than those breeding on St. George Island.

The distributions of murres at sea shows that birds breeding on St. Paul Island foraged farther from the colonies than did the birds breeding on St. George Island. Schneider \& Hunt (1984) suggested that birds from the 2 islands are exposed to different foraging habitats. In particular, birds on St. George Island have ready access to highly productive areas of the outer shelf of the Bering Sea and a relatively short commute to the shelf edge compared to birds on St. Paul Island. Larger distances between foraging grounds and colonies are in parallel with the higher FMRs of parent thick-billed murres breeding on St. Paul Island compared to St. George Island reported here. Perhaps the successful reproduction of thick-billed murres at the colonies on St. Paul Island requires an additional energy expenditure in foraging, which resulted in the increased energy expenditure of parent murres on St. Paul compared to St. George Island.

Another possible explanation for differences in FMRs found between murres on St. Paul and St. George Islands is that the measured differences might result from 'sampling error'. Several studies (deForest \& Gaston 1996, Hipfner 1997, Hipfner \& Gaston 1999) have shown that parent thick-billed murres nesting at the same colony differ in their quality and reproductive performance. Coulson \& Porter (1985) reported similar differences in the quality of black-legged kittiwake parents nesting at North Shields in England. In our study, all birds were chosen randomly and, ideally, should have represented all individuals including those of poor, intermediate and high quality. However, the greater foraging distances that birds had to travel 
from the colonies of St. Paul Island could cause an early reproductive failure of poor-quality parents. Because we measured FMRs of birds feeding chicks, a majority of poor-quality parents could either have never laid eggs, or had already lost their eggs/chicks by the time of the FMR measurements. The proportion of good-quality birds sampled, which still retained their chicks, could be then relatively higher at St. Paul Island. Thus, our measurements of FMRs in thickbilled murres on St. Paul Island may represent reproductive investment of high-quality birds that could endure a significant increase in energy expenditures associated with large foraging distances. At the same time, murres breeding on St. George Island foraged in close vicinity to the island, and a difference in reproductive failure between poor- and high-quality parents may have been expressed less than on St. Paul Island. Consequently, at St. George Island we may have measured field metabolic rates of both poor- and highquality parent thick-billed murres, which could have resulted in a lower average FMRs among thick-billed murres breeding on St. George Island than on St. Paul Island. The finding that larger proportions (Climo 1993, Dragoo \& Dragoo 1994) of thick-billed murres lost their eggs on St. Paul Island (36\% in 1987, $37 \%$ in 1988) than on St. George Island (25\% in both years) provides indirect evidence for this hypothesis. It is not known whether poor- and high-quality parent thickbilled murres differ in daily energy expenditures during chick-rearing, and this question requires thorough investigation.

Parent murres do not provide food at a rate that would support chick maximal growth and development (Harris \& Wanless 1995, Kitaysky 1996). On the other hand, it is also likely that parent murres do not provide food at a rate lower than some lowest possible rate, which would still allow a chick to survive and fledge successfully. A cost to a parent murre of keeping such a rate of food provisioning might vary with fluctuations in foraging conditions, and could reflect the longer foraging distances of parent thick-billed murres breeding on St. Paul Island compared to those on St. George Island. Our analysis of long-term variability of growth of thickbilled murre chicks at the Pribilof Islands provides indirect evidence for this. In particular, the maximal chick growth rate was $60 \%$ above the long-term mean $(8.4 \mathrm{~g}$ $\mathrm{d}^{-1}$ ), whereas the minimal chick growth rate was only $25 \%$ below the long-term mean (Fig. 9).

\section{Reproductive strategies}

Fluctuations in food abundance influence different parameters of reproductive performance in blacklegged kittiwakes and thick-billed murres, which should be taken into account during ecological studies of these birds. In particular, the results of our study show that parent black-legged kittiwakes are able/ willing to compensate for food shortages by expanding their foraging ranges and investing more energy in reproduction. This parental strategy results in a relatively low inter-seasonal variation of chick growth rates (Fig. 8). For example, the daily increment of captive black-legged kittiwake chicks fed ad libitum varied between $13.3 \mathrm{~g} \mathrm{~d}^{-1}$ (M. Romano unpubl.) and $14.1 \mathrm{~g}$ $\mathrm{d}^{-1}$ (Kitaysky \& Belogubova 1988). These values are within the range of growth rates of wild black-legged kittiwake chicks recorded in our study (Fig. 6). Thus, when food availability varies, parent kittiwakes adjust their provisioning efforts to compensate for these variations. Similar evidence for low variation in chick growth rates were reported in a long-term study of black-legged kittiwakes in England (Coulson \& Porter 1985) and among tropical seabirds feeding their young during food shortages (Shea \& Ricklefs 1996), suggesting that this parental strategy is not confined to blacklegged kittiwakes nesting at the Pribilof Islands.

The functional importance of the food-provisioning strategy of black-legged kittiwakes is not known. Several explanations seem possible. First, kittiwake chicks are physiologically sensitive to variations in daily food intake and respond to moderate food shortages by a chronic elevation of stress hormones (Kitaysky et al. 1999). Chronic elevation of stress hormones is known to suppress memory and immune systems, promote wasting of muscle tissue, and cause neuronal cell death (Sapolsky et al. 1986, Sapolsky 1992, also reviewed in Wingfield 1994). Impaired physiological conditions of under-nourished black-legged kittiwake chicks might decrease their chances of survival. This would force their parents to provide food on chick demand (Kitaysky et al. 1999). Second, the food-provisioning strategy of parent black-legged kittiwakes may be phylogenetically determined. Although pelagic-foraging kittiwakes rely on more variable food resources compared to their inshore foraging counterparts, chick-provisioning behavior of kittiwakes is still similar to that of other species of gulls (e.g., Harris 1970, Henderson 1975, for references see also Ydenberg \& Bertram 1989).

In contrast to kittiwakes, parent murres seem to provision young with food in accordance to variations in foraging conditions rather than in response to chick demands (Houston et al. 1996, and references therein). This parental strategy results in large fluctuations of chick growth rates (Fig. 9) and probably in a variable duration of chick development in the nest (Houston et al. 1996). In particular, Gaston \& Nettleship (1981) and Hunt et al. (1986) have shown that the duration of murre chick development in the nest is shorter in large 
colonies than in small colonies. These authors hypothesized that if depletion of food resources occurs faster in the vicinity of a large colony compared to a small colony, parent murres can avoid some of the negative effects of food shortages on their reproduction by fledging their chicks and moving with them to regions of the ocean where food is abundant. Hunt et al. (1986) provided correlative evidence for this hypothesis by comparing fledging age of thick-billed murre chicks between St. Paul and St. George Islands. When food for parent thick-billed murres is scarce, the short duration of their chick development and a reduced daily energy expenditure in feeding their young would preserve available resources and probably increase postbreeding survival of those parents.

Acknowledgements. We thank the many undergraduate and graduate students and University Research Expedition personnel who helped in the field and during laboratory analyses. I. Jones, R. Squibb and the late Peter Prince were especially helpful on the islands, and K. Nagy provided great help with analyses. An anonymous referee, J. F. Piatt, and K. Sullivan provided useful comments on earlier versions of the manuscript. Financial support for this study was provided through NSF grant no. DPP 85-21178 to G.L.H. Final work on the manuscript was supported through EVOS Trustee Council Restoration Project No. 99479 to A.S.K. The Tanagusix and Tanaq corporations of the Pribilof Islands granted permission to work on the islands. The manipulations of birds were in accordance with protocol approved by the Institutional Animal Care and Use Committee of the University of California, Irvine.

\section{LITERATURE CITED}

Ainley DG, Boekelheide RJ (1990) Seabirds of the Farallon Islands. Stanford University Press, Stanford, CA

Arcese P, Smith JNM (1988) Effects of population density and supplemental food on reproduction in song sparrows. J Anim Ecol 57:119-136

Ashmole NP (1963) The regulation of numbers of tropical oceanic birds. Ibis 103b:458-473

Barret RT, Runde OJ (1980) Growth and survival of nesting Kittiwakes Rissa tridactyla in Norway. Ornis Scand 11: 228-235

Both C (1998) Experimental evidence for density dependence of reproduction in great tits. J Anim Ecol 67:667-674

Braun BM, Hunt GL (1983) Brood reduction in black-legged kittiwakes. Auk 100:469-476

Burger AE, Piatt JF (1990) Flexible time budgets in breeding Common Murres: buffers against variable prey availability. Stud Avian Biol 14:71-83

Climo L (1993) The status of cliff-nesting seabirds at St. Paul Island, Alaska in 1992. US Fish Wildl Serv, AMNWR 93/15, Homer, AK

Cooch EG, Ricklefs RE (1994) Do variable environments significantly influence optimal reproductive effort in birds? Oikos 69:447-459

Coulson JC, Porter JM (1985) Reproductive success of the Kittiwake Rissa tridactyla: the roles of clutch size, chick growth rates and parental quality. Ibis 127:450-466
Coyle KO, Cooney RT (1993) Water column sound scattering and hydrography around the Pribilof Islands, Bering Sea. Cont Shelf Res 13:803-827

Craighead FL, Oppenheim J (1982) Population estimates and temporal trends of Pribilof Island seabirds. Alaska Biological Research to NOAA, Alaska Office, Juneau, AK

Decker MB (1995) Influences of oceanographic proccesses on seabird ecology. PhD thesis, University of California, Irvine

Decker MB, Hunt GL, Byrd GV (1995) The relationships among sea-surface temperature, the abundance of juvenile walley pollock (Theragra chalcogramma) and the reproductive performance and diets of seabirds at the Pribilof Islands, southeastern Bering Sea. Can Spec Publ Fish Aquat Sci 121:425-437

deForest LN, Gaston AJ (1996) The effects of age on timing and breeding success in the thick-billed murre. Ecology 77:1501-1511

Dragoo DE, Dragoo BK (1994) Results of productivity monitoring of kittiwakes and murres at St. George Island, Alaska in 1993. Rep Dir Fish Wildl Serv Report, AMNWR 94/06, Homer, AK

Furness RW (1984) Modelling relationships among fisheries, seabirds, and marine mammals. In: Nettleship DN, Sanger GA (eds) Marine birds: their feeding ecology and commercial fisheries relationship. Spec Publ Can Wildl Serv Ottawa, p 117-126

Furness RW, Birkhead TR (1984) Seabird colony distribution suggests competition for food supplies during the breeding season. Nature 311:655-656

Furness RW, Nettleship DN (1991) Introductory remarks: seabirds as monitors of changing marine environments. In: Proc Int Ornithol Congr 20:2239-2240

Gabrielsen GW, Mehlum F, Nagy KA (1987) Daily energy expenditure and energy utilization of free-ranging blacklegged kittiwakes. Condor 89:126-132

Gaston AJ (1985) Energy invested in reproduction by thickbilled murres (Uria lomvia). Auk 102:447-458

Gaston AJ, Jones IL (1998) The auks Alcidae. Oxford University Press, New York

Gaston AJ, Nettleship DN (1981) The thick-billed murres of Prince Leopold Island. Monogr Ser Can Wildl Serv 6, Canadian Wildlife Service, Ottawa

Greenstreet SPR, Becker PH, Barrett RT, Fossum P, Leopold MF (1999) Consumption of pre-recruit fish by seabirds and the possible use of this as an indicator of fish stock recruitment. ICES Co-op Res Rep 232:6-17

Harris MP (1970) Breeding ecology of the Swallow-tailed Gull (Creagrus furcatus). Auk 87:215-243

Harris MP, Wanless S (1995) The food consumption of young common murres (Uria aalge) in the wild. Colon Waterbirds 18:209-213

Henderson BA (1975) Role of the chick's begging behavior in the regulation of parental feeding behavior of Larus glaucescens. Condor 77:488-492

Hickey JJ, Craighead FL (1977) A census on the Pribilof Islands. Environmental Assessment of the Alaskan Continental Shelf. Annual reports of Principal Investigators. NOAA Environmental Research Laboratories, Boulder, CO, p 95-195

Hipfner JM (1997) The effects of parent quality and timing of breeding on the growth of nestling thick-billed murres. Condor 99:353-360

Hipfner JM, Gaston AJ (1999) Timing of nest departure in the thick-billed murre and Razorbill: test of Ydenberg's model. Ecology 80:587-596

Houston AI, Thompson WA, Gaston AJ (1996) The use of time 
and energy budget model of a parent bird to investigate limits to fledging mass in the thick-billed murre. Funct Ecol 10:432-439

Hunt GL, Byrd GV (1999) Marine bird populations and carrying capacity of the eastern Bering Sea. In: Louphlin TR, Otani K (eds) Dynamics of the Bering Sea. University of Alaska Sea Grant, Fairbanks, AK, p 631-650

Hunt GL, Eppley ZA, Burgeson B, Squibb R (1982) Reproductive ecology, foods and foraging areas of seabirds nesting on the Pribilof Islands, 1975-1979. Environmental assessment of the Alaskan Continental Shelf. NOAA Environmental Research Laboratories, Boulder, CO, p 1-258

Hunt GL, Eppley ZA, Schneider DC (1986) Reproductive performance of seabirds: the importance of population and colony size. Auk 103:306-317

Hunt GL, Barrett RT, Joiris C, Montevecchi WA (1996) Seabirds/fish interactions: an introduction. ICES Co-op Res Rep 216:2-5

Kitaysky AS (1996) Behavioral, physiological and reproductive responses of alcids (Alcidae) to variation in food availability. PhD thesis, University of California, Irvine

Kitaysky AS, Belogubova EG (1988) Energetic aspects of kittiwake (Rissa tridactyla) nestlings growth. In: Andreev AV, Kondratyev AY (eds) Studies and protection of birds in Northern ecosystems. USSR Academy of Sciences, Vladivostok: Far-Eastern Branch, p 68-76

Kitaysky AS, Golubova EG (2000) Climate change causes contrasting trends in reproductive performance of planktivorous and piscivorous alcids. J Anim Ecol 69:248-262

Kitaysky AS, Piatt JF, Wingfield JC, Romano M (1999) The adrenocortical stress-response of black-legged kittiwake chicks in relation to dietary restrictions. J Comp Physiol (Sect B) 169:303-310

Mognahan P, Walton P, Wanless S, Uttley JD, Burns MD (1994) Effects of prey abundance on the foraging behaviour, diving efficiency and time allocation of breeding Guillemots Uria aalge. Ibis 136:214-222

Montevecchi WA (1993) Birds as indicators of change in marine prey stocks. In: Furness RW, Greenwood JJD (eds) Birds as monitors of environmental change. Chapman \& Hall, London, p 217-266

Nagy KA (1983) The doubly labelled water $\left({ }^{3} \mathrm{HH}^{18} \mathrm{O}\right)$ method: a guide to its use. University of California, Los Angeles (Publ No. 12-1417)

Nagy KA, Costa DP (1980) Water flux in animals: analysis of potential errors in the tritiated water method. Am J Physiol 238:R454-R465

Obst BS, Russell RW, Hunt GL, Eppley ZA, Harrison NM (1995) Foraging radii and energetics of Least Auklets (Aethia pusilla) breeding on three Bering Sea islands. Physiol Zool 68:647-672

Editorial responsibility: Otto Kinne (Editor), Oldendorf/Luhe, Germany
Packard GC, Boardman TJ (1987a) The misuse of ratios, indices, and percentages in ecophysiological research. Physiol Zool 61:1-9

Packard GC, Boardman TJ (1987b) The misuse of ratios to scale physiological data that vary allometrically with body size. In: Feder ME, Bennett AF, Burggren WW, Huey RB (eds) New directions in ecological physiology. Cambridge University Press, Cambridge, p 216-235

Roby DD, Ricklefs RE (1986) Energy expenditure in adult least auklets and diving petrels during the chick-rearing period. Physiol Zool 59:661-678

Sapolsky RM (1992) Neuroendocrinology of the stressresponse. In: Becker JB, Breedlove SM, Crews D (eds) Behavioral endocrinology. A Bradford book. The MIT Press, Cambridge, MA, p 287-324

Sapolsky RM, Krey LC, McEwen BS (1986) The neuroendocrinology of stress and aging: the glucocorticosteroid cascade hypothesis. Endocr Rev 7:284-301

Schneider D, Hunt GL (1984) A comparison of seabird diets and foraging distribution around the Pribilof Islands, Alaska. In: Nettleship DN, Sanger GA, Springer PF (eds) Marine birds: their feeding ecology and commercial fisheries relationships. Spec Publ Can Wildl Serv, Ottawa, p 86-95

Shea RE, Ricklefs RE (1996) Temporal variation in growth performance in six species of tropical, pelagic seabirds. J Anim Ecol 65:29-42

Sokal RR, Rohlf FJ (1981) Biometry. The principles and practise of statistics in biological research, 2nd edn. WH Freeman \& Co, New York

Stearns SC (1992) The evolution of life histories. Oxford University Press, Oxford

Uttley JD, Walton P, Monaghan P, Austin G (1994) The effects of food abundance on breeding performance and adult time budgets of Guillemots Uria aalge. Ibis 136:205-213

Wilkinson L (1992) Systat for Windows. SYSTAT Inc, Evanston, IL

Wingfield JC (1994) Modulation of the adrenocortical response to stress in birds. In: Davey KG, Peter RE, Tobe SS (eds) Perspectives in comparative endocrinology. National Research Council of Canada, Ottawa, p 520-528

Wood RA, Nagy KA, MacDonald NS, Wakakuwa ST, Beckman RJ, Kaaz H (1975) Determination of oxygen-18 in water contained in biological samples by charged particle activation. Analyt Chem 47:646-650

Ydenberg RC, Bertram DF (1989) Lack's clutch size hypothesis and brood enlargement studies on colonial seabirds. Colon Waterbirds 12:134-137

Zador SG, Piatt JF (1999) Time-budgets of common murres at a declining and increasing colony in Alaska. Condor 101:149-152

Submitted: November 23, 1999; Accepted: May 25, 2000

Proofs received from author(s): October 5, 2000 